\title{
Silencing of hypoxia-inducible factor-1 $\alpha$ promotes thyroid cancer cell apoptosis and inhibits invasion by downregulating WWP2, WWP9, VEGF and VEGFR2
}

\author{
ZHONG-YANG DING ${ }^{1}$, YUN-JUAN HUANG ${ }^{2}$, JIAN-DONG TANG $^{1}$, \\ GAN LI ${ }^{1}$, PAN-QIANG JIANG ${ }^{1}$ and HAO-TIAN WU ${ }^{1}$ \\ ${ }^{1}$ Department of General Surgery, Wuxi Chinese Medicine Hospital Affiliated by Nanjing, Chinese Medicine \\ University; ${ }^{2}$ Department of Nursery, Wuxi People's Hospital, Wuxi, Jiangsu 214023, P.R. China
}

Received July 6, 2015; Accepted September 1, 2016

DOI: $10.3892 /$ etm.2016.3826

\begin{abstract}
Adaptation to hypoxia is an important process physiologically and pathologically. Hypoxia-inducible factor- $1 \alpha$ (HIF-1 $\alpha)$ participates in the cancer biology of numerous endocrine tumors, including their proliferation and differentiation. In the present study, the hypothesis that HIF-1 $\alpha$ promotes tumorigenesis in thyroid cancer via upregulating angiogenesis-associated markers is investigated. Reverse transcription-quantitative polymerase chain reaction (RT-qPCR) and western blot analysis were used to examine the expression of HIF-1 $\alpha$ in thyroid cancer cell lines, and to detect the expression of WW domain containing E3 ubiquitin protein ligase (WWP)2, WWP9, vascular endothelial growth factor (VEGF) and VEGF receptor 2 (VEGFR2) in MZ-CRC-1 and TT thyroid cancer cells. Cell proliferation was measured using a Cell Count Kit-8. Cell apoptosis and cell cycle was assessed by flow cytometry. Cell invasive ability was examined by Matrigel transwell analysis. RT-qPCR and western blot analyses demonstrated that the mRNA and protein expression levels of HIF-1 $\alpha$ were significant higher in MZ-CRC-1 and TT thyroid cancer cells than in another three thyroid cancer cells $(\mathrm{P}<0.01)$. HIF-1 $\alpha$ knockdown cells demonstrated inhibition of cell proliferation and invasion, arrested cell cycle at the G1 phase, and induction of cell apoptosis. The protein expression levels of WWP2, WWP9, VEGF and VEGFR2 were decreased in HIF-1 $\alpha$ knockdown MZ-CRC-1 and TT cells. In conclusion, HIF-1 $\alpha$ may be important in cell apoptosis and invasion of thyroid cancer cells, likely through regulating WWP2, WWP9, VEGF and VEGFR2 expression.
\end{abstract}

Correspondence to: Dr Yun-Juan Huang, Department of Nursery, Wuxi People's Hospital, 299 Qingyang Road, Wuxi, Jiangsu 214023, P.R. China

E-mail: huang_yj11@126.com

Key words: thyroid cancer, hypoxia, hypoxia-inducible factor-1 $\alpha$, invasion, angiogenesis

\section{Introduction}

Thyroid cancer has been considered to be the most common malignancy of endocrine organs and its incidence is increasing (1). The definitive molecular mechanisms contributing towards the development and progression of thyroid cancer are partially unknown. Papillary thyroid cancer is the most frequent thyroid cancer, accounting for $85-90 \%$ of all thyroid malignancies $(2,3)$. Medullary thyroid cancer is a rare malignancy, accounting for 3-10\% of all thyroid cancer, and is responsible for $\leq 13.4 \%$ of all mortalities associated with this disease (4).

Hypoxia is common in solid tumors and is defined as a loss of oxygen in tissues. Oxygen tension in tumors is $\sim 1.5 \%$ oxygen; however, in normal tissues this is $\sim 7 \%$ (5). Tumor hypoxia is responsible for the cause of several types of cancer with a poor prognosis (6). In turn, these hypoxic adaptive tumors are more difficult to treat and confer increased resistance to chemotherapy and radiotherapy (7).

Hypoxia-inducible factor 1 (HIF-1) complex, consisting of two submits, the oxygen-sensitive HIF-1 $\alpha$ and the constitutively expressed HIF-1 $\beta$, participates in the cancer biology of numerous endocrine tumors. It is estimated that as much as $1 \%$ of the genome is hypoxia regulated (8). Under normoxic conditions, HIF-1 $\alpha$ is rapidly inactivated and binds to the Hippel-Lindau protein through hydroxylation, followed by degradation in the proteasome via the ubiquitination signaling pathway (9). In hypoxia, HIF-1 $\alpha$ translocates to the nucleus and activates HIF-responsive genes, following heterodimerization with HIF-1 $\beta$ and cofactors (10). Previous data characterizing the potential role of HIF-1 $\alpha$ in thyroid cancer cells are limited. High levels of HIF-1 $\alpha$ mRNA and protein were observed in papillary thyroid cancer tissues (11), and reporter gene activity is upregulated in response to a reduction of oxygen tension and to stimulation by $\mathrm{CoCl}_{2}$ treatment, thus causing increased levels of the HIF-1 $\alpha$ target genes (12).

Angiogenesis is important since it is essential for the other biological characteristics in cancer (13). Investigations have demonstrated that it is a complicated multistep and temporal order process involving in a number of genes and pathways 
regulated by HIF-1 $\alpha$, such as nitric oxide synthase, WW domain containing E3 ubiquitin protein ligase (WWP)28, vascular endothelial growth factor (VEGF), and other genes regulated by HIF-1 $\alpha$ directly or indirectly (14-16). However, there is no evidence suggesting that HIF-1 $\alpha$ regulates angiogenic gene expression and correlates with angiogenic potential, which influences the biological progression, such as cell proliferation, apoptosis and invasion.

In the present study, the effect of HIF-1 $\alpha$ on proliferation, cell cycle, apoptosis and invasion in thyroid cancer cells is investigated. The hypothesis that HIF-1 $\alpha$, as a tumor promoter, induces cell proliferation and invasion and inhibits cell apoptosis via regulating angiogenic gene expression in MZ-CRC-1 and TT thyroid cancer cells, is explored.

\section{Materials and methods}

Cell culture. Thyroid cancer cell lines derived from MZ-CRC-1, TT, FTC-133, TPC-1 and SW579 were obtained from the Cell Bank of Academia Sinica (Shanghai, China). Cells were maintained in Dulbecco's modified Eagle medium (DMEM) supplemented with $10 \%$ fetal bovine serum (FBS; Thermo Fisher Scientific, Inc., Waltham, MA, USA) in a humidified incubator containing $5 \% \mathrm{CO}_{2}$ in air at $37^{\circ} \mathrm{C}$.

Transfection of HIF-1a short hairpin (sh)RNA. shRNA for HIF-1 $\alpha$ (20 nM) was obtained from Genesil Biotechnology Co., Ltd. (Wuhan, China). The shRNA targeted position 602-624 (GGCCAGAAUCAUUCCUAGUUU) of human HIF-1 $\alpha$ mRNA. Transfection of thyroid cancer cells was performed with Lipofectamine 2000 (Thermo Fisher Scientific, Inc.), according to the manufacturer's instructions. An empty vector was used as a negative control (NC), and the selective downregulation of HIF-1 $\alpha$ was identified by reverse transcription-quantitative polymerase chain reaction (RT-qPCR) analysis. The thyroid cancer cells were analyzed $48 \mathrm{~h}$ after transfection.

$R T$ - $q P C R$. Total RNA were extracted from thyroid cancer cells with TRIzol reagent (Thermo Fisher Scientific, Inc.), as previously described (17) and stored at $-80^{\circ} \mathrm{C}$. Prior to reverse transcription, RNA was treated with DNase (Invitrogen; Thermo Fisher Scientific, Inc.). cDNA was synthesized using a RevertAid First Strand cDNA Synthesis Kit (K1622; Thermo Fisher Scientific, Inc.). A Maxima SYBR Green/ ROX qPCR Master Mix kit (K0223; Thermo Fisher Scientific, Inc.) was used according to the manufacturer's instructions. The primers sequences (sense/antisense) used were list as follows: HIF-1a, 5'-TCGGCGAAGTAAAGAATC-3' and 5'-TTCCTCACACGCAAATAG-3'; GAPDH: 5'-CACCCA CTCCTCCACCTTTG-3' and 5'-CCACCACCCTGTTGC TGTAG-3'. The PCR cycling conditions were as follows: $95^{\circ} \mathrm{C}$ for $10 \mathrm{~min}$, followed by 40 cycles at $95^{\circ} \mathrm{C}$ for $15 \mathrm{sec}$ and $60^{\circ} \mathrm{C}$ for $45 \mathrm{sec}$, and a final extension step of $95^{\circ} \mathrm{C}$ for $15 \mathrm{sec}, 60^{\circ} \mathrm{C}$ for $1 \mathrm{~min}, 95^{\circ} \mathrm{C}$ for $15 \mathrm{sec}$ and $60^{\circ} \mathrm{C}$ for $15 \mathrm{sec}$. Expression levels were normalized against GAPDH and measured in triplicate. The gene expression was calculated using the $2^{-\Delta \Delta \mathrm{Ct}}$ method. Relative quantification of the signals was performed by normalizing the signals of different genes against the GAPDH signal.
Western blot analysis. Total protein was isolated from thyroid cancer cell lines. Proteins were isolated using radioimmunoprecipitation buffer (Wuhan Amyjet Scientific, Inc., Wuhan, China) at $10 \mathrm{~min}$ at $95^{\circ} \mathrm{C}$, then centrifuged at $400 \mathrm{x} g$ at $25^{\circ} \mathrm{C}$ for $10 \mathrm{~min}$. The protein concentration was measured using a BCA protein assay kit (Pierce Biotechnology, Inc., Rockford, IL, USA). Total protein (50 $\mu \mathrm{g})$ was separated using $10 \%$ SDS-PAGE (Wuhan Amyjet Scientific, Inc.). Proteins were then transferred to polyvinylidene difluoride membranes (Sigma-Aldrich; Merck Millipore,Darmstadt, Germany), which were blocked with fat-free milk for $1 \mathrm{~h}$ at $25^{\circ} \mathrm{C}$. The membrane was washed and incubated with rabbit monoclonal anti-HIF-1 $\alpha$ (ab31358; Abcam, Cambridge, UK) and anti-GAPDH (5174S; Cell Signaling Technology, Inc., Danvers, MA, USA) for $2 \mathrm{~h}$ at $25^{\circ} \mathrm{C}$. The membranes were subsequently washed three times with Tris-buffered saline with Tween 20 (TBST; AMRESCO, Solon, OH, USA). The membranes were then incubated with horseradish peroxidase-conjugated goat anti-rabbit $\operatorname{IgG}(1,000$; A0208; Beyotime Institute of Biotechnology, Haimen, China) secondary antibodies for $1 \mathrm{~h}$ at $37^{\circ} \mathrm{C}$, and washed three times with TBST. Membranes were visualized using an enhanced chemiluminescence kit (WBKLS0100; Merck Millipore), and signal intensity was determined by Image $\mathbf{J}$ software (imagej. nih.gov/ij/).

Cell proliferation assay. Cell proliferation was performed by using CCK-8 assay (Beyotime Institute of Biotechnology, Haimen, China), according to manufacturer's instructions. Briefly, $2 \times 10^{3}$ cells/well of MZ-CRC-1 and TT cells were cultured onto 96-well plates. After incubation, $10 \mu \mathrm{l} \mathrm{CCK}-8$ reagent was added and incubated at $37^{\circ} \mathrm{C}$. Absorbance was measured using a microplate reader at $450 \mathrm{~nm}$.

Cell cycle assay. MZ-CRC-1 and TT cells were seeded in 12 -well plates following HIF-1 $\alpha$ shRNA transfection for $48 \mathrm{~h}$. The percentage of cells in the different phases of the cell cycle were evaluated using propidium iodide (PI) staining (BioVision, Inc., Mountain View, CA, USA). Briefly, cells were washed with phosphate-buffered saline (PBS), trypsinized and centrifuged at $1,000 \times \mathrm{g}$ at $4^{\circ} \mathrm{C}$ for $5 \mathrm{~min}$. Pellets were fixed overnight in $70 \%$ cold ethanol and incubated in PBS containing RNase $(1 \mathrm{mg} / \mathrm{ml})$ for $10 \mathrm{~min}$ at room temperature. Finally, samples were stained with PI $(1 \mathrm{mg} / \mathrm{ml})$ for $30 \mathrm{~min}$ at $4{ }^{\circ} \mathrm{C}$. Data acquisition was analyzed by flow cytometry and Cell Quest software (Beckman Coulter, Inc., Brea, CA, USA).

Apoptosis assay. For apoptosis analysis, cells were seeded onto 6 -well plates and transfected with HIF-1 $\alpha$ shRNA. At $48 \mathrm{~h}$ after transfection, cells were collected, washed, and stained using a AnnexinV/PI double staining kit (BD Biosciences, Bedford, MA, USA), according to the manufacturer's instructions. Apoptotic cells were analyzed by flow cytometery.

Invasion assay. The MZ-CRC-1 and TT cells invasive ability with HIF-1 $\alpha$ shRNA treatment was examined using a membrane transwell culture system. Briefly, transwell membrane coated with Matrigel (2.5 mg/ml; BD Biosciences) was used for the invasion assay. Cells were trypsinized, centrifuged, and resuspended at $10^{5}$ cells/ml in DMEM (with $1 \%$ FBS). Cells that migrated into the lower well were washed 
A
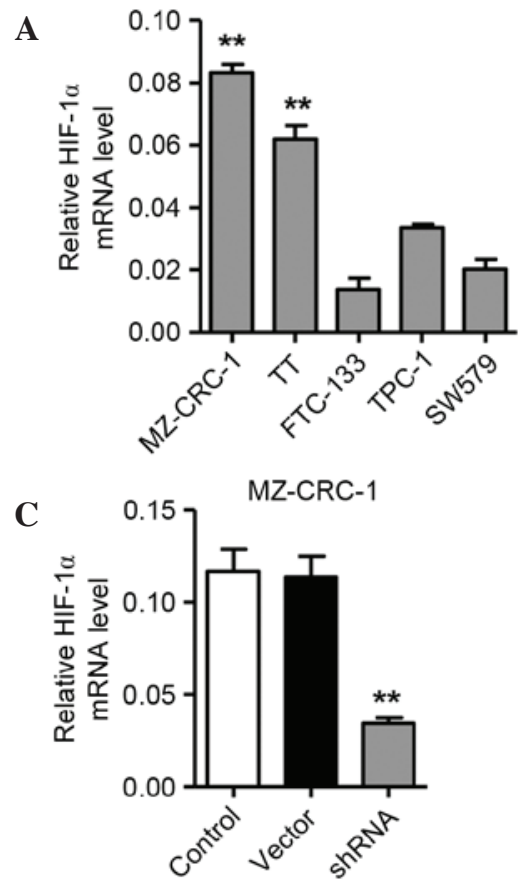

$\mathbf{E}$

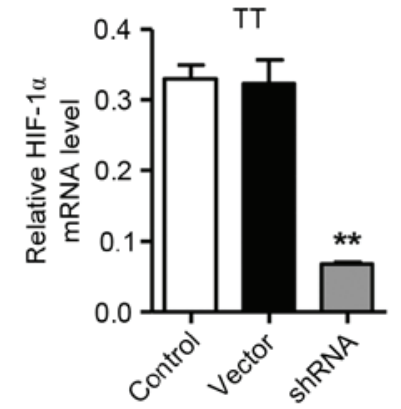

B
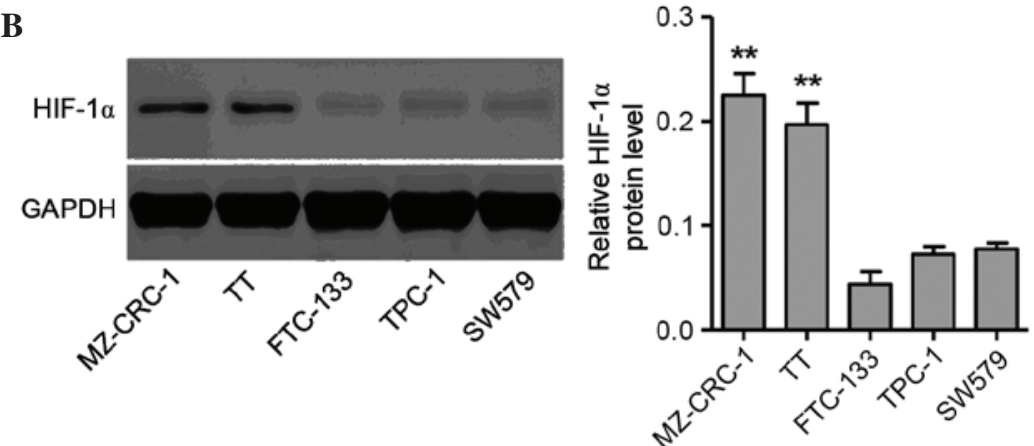

D
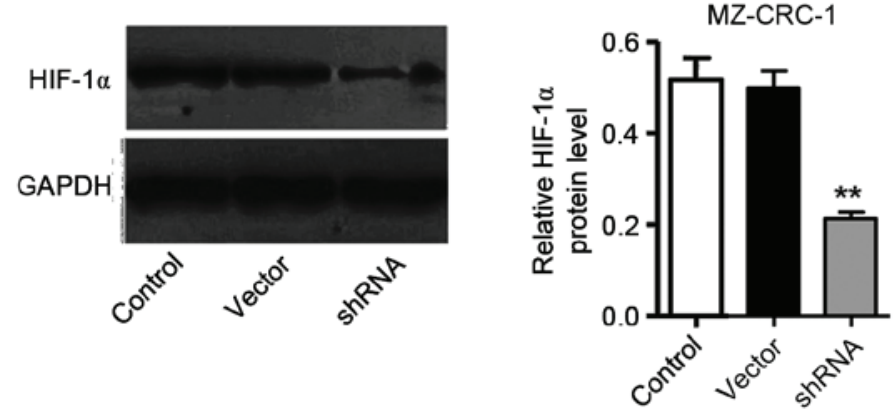

$\mathbf{F}$
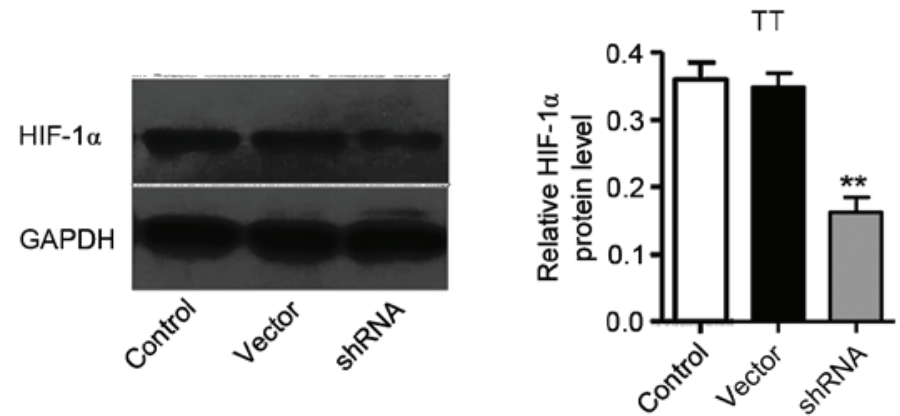

Figure 1. Expression of HIF-1 $\alpha$ in thyroid cancer cell lines and knockdown by shRNA. (A) mRNA and (B) protein expression of HIF-1 $\alpha$ in thyroid cancer cell lines TT, TPC-1, FTC-133, SW579 and MZ-CRC-1. Reverse transcription-quantitative polymerase chain reaction and western blot analysis identified a significant decrease in HIF-1 $\alpha$ expression in MZ-CRC-1 cell (C) mRNA and (D) protein levels and TT cell (E) mRNA and (F) protein levels with stable knockdown of HIF-1 $\alpha .{ }^{* *} \mathrm{P}<0.01$ vs (A and B) FTC-133 cells or (C-F) control groups. HIF-1 $\alpha$, hypoxia-inducible factor-1 $\alpha$; shRNA, small hairpin RNA.

A

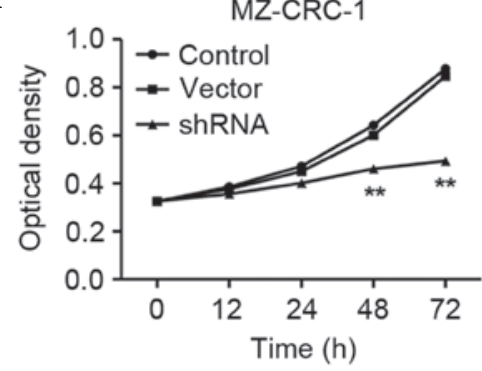

B

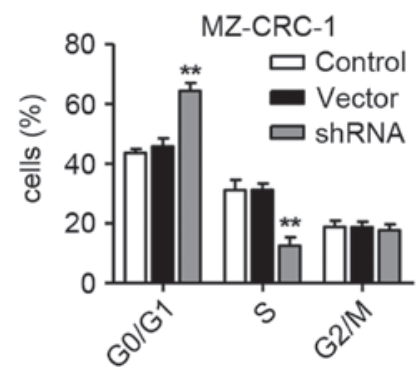

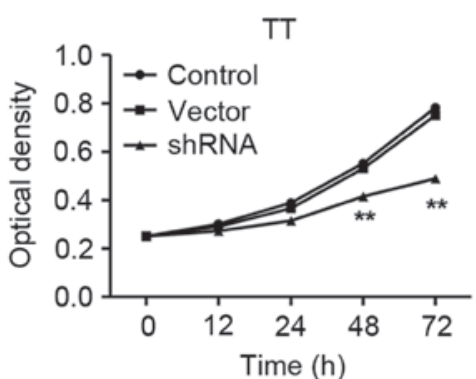

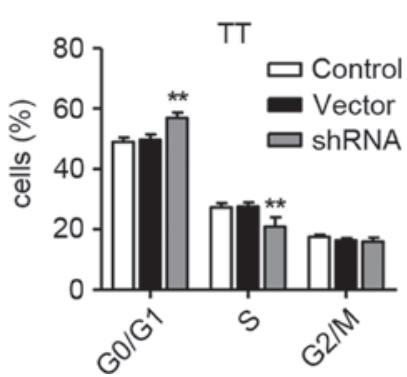

Figure 2. Effects of HIF-1 $\alpha$ on cell proliferation and cell cycle in vitro. (A) Cell Count Kit-8 analysis identified an inhibition of cell proliferation in MZ-CRC-1 and TT cells. (B) Flow cytometry analysis identified an arrest of cell cycle in MZ-CRC-1 and TT cells. ${ }^{* *} \mathrm{P}<0.01$ vs control groups. HIF-1 $\alpha$, hypoxia-inducible factor-1 $\alpha$; shRNA, small hairpin RNA; M, mitotic phase; S, synthesis phase. 

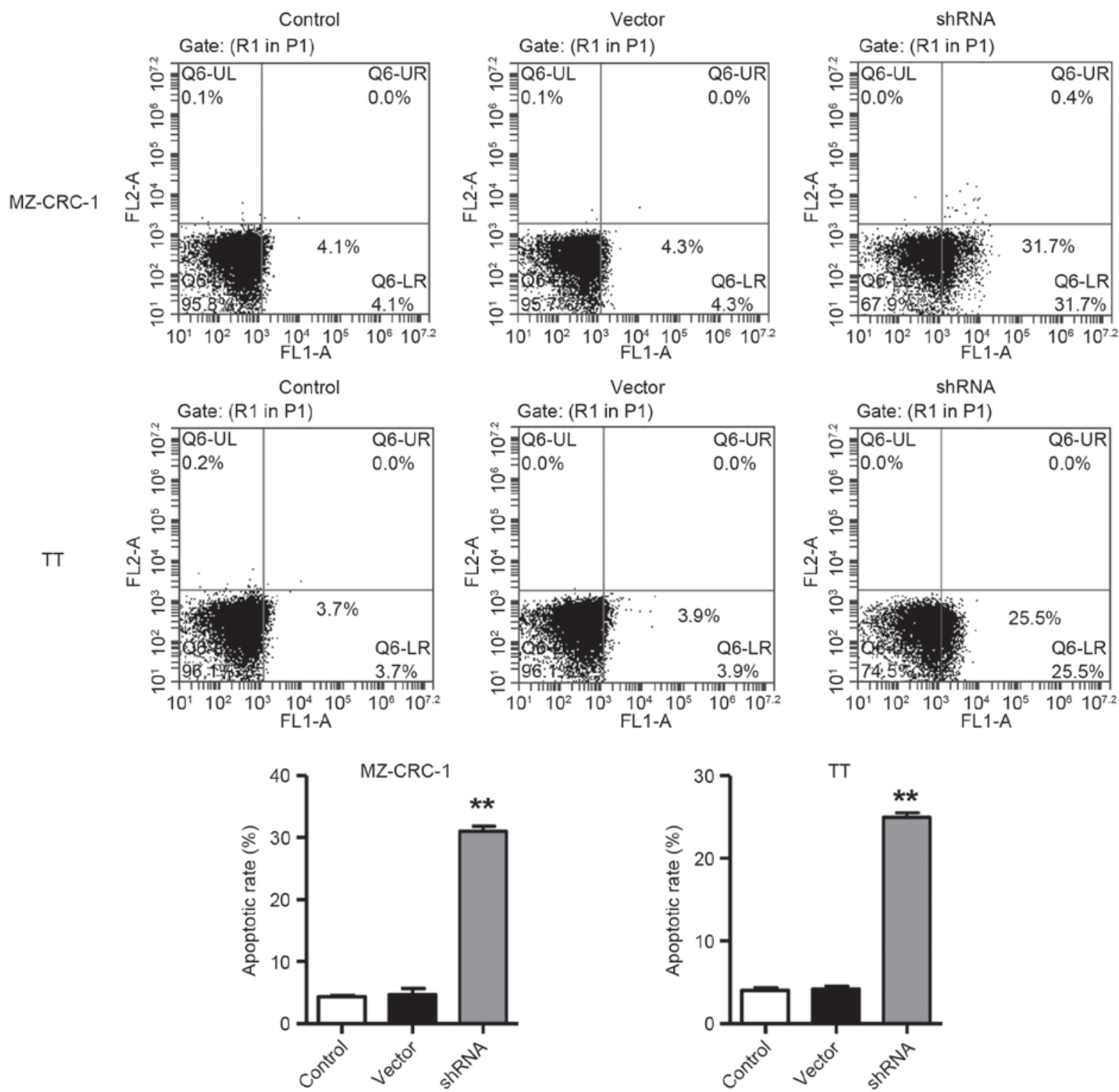

Figure 3. Effects of hypoxia-inducible factor-1 $\alpha$ on cell apoptosis in vitro. Flow cytometry analysis was performed to determine the apoptotic rate of MZ-CRC-1 and TT cells. ${ }^{* *} \mathrm{P}<0.01$ vs. the vector group. shRNA, small hairpin RNA.

with PBS, fixed in $4 \%$ paraformaldehyde and stained by $0.5 \%$ crystal violet. Cells were photographed and counted using an inverted microscope (XDS-500C; Shanghai Caikon Optical Instrument Co., Ltd, Shanghai, China)..

Statistical analysis. Statistical analysis was performed using GraphPad Prism 5 software (GraphPad Software, Inc., La Jolla, CA, USA). Data are presented as the mean \pm standard deviation. All in vitro experiments were performed in triplicate. Paired, two-tailed Student's t-test was used to analyze the difference between groups. $\mathrm{P}<0.01$ was considered to indicate a statistically significant difference.

\section{Results}

Expression of HIF-1 $\alpha$ in thyroid cancer cell lines. To understand the gene regulatory mechanism of HIF-1 $\alpha$, its expression levels in five thyroid cancer cell lines, including MZ-CRC-1, TT, FTC-133, TPC-1 and SW579, were investigated. RNA was isolated from each thyroid cancer cell line and the expression of HIF- $1 \alpha$ was analyzed by RT-qPCR and western blotting. These analyses indicated that HIF-1 $\alpha$ expression (mRNA and protein levels) was significantly higher in MZ-CRC-1 and TT cells compared with the three other cell lines (Fig. 1A and B; $\mathrm{P}<0.01)$. As a result, MZ-CRC-1 and TT cells were used for the following experiments with HIF- $1 \alpha$.

Downregulation of HIF-1 $\alpha$ by shRNA in MZ-CRC-1 and TT cells. In order to knockdown HIF-1 $\alpha$, a sequence expressing shRNA targeting HIF-1 $\alpha$ was introduced into MZ-CRC-1 and TT cells to knockdown the expression of HIF-1 $\alpha$. The efficacy of knockdown of HIF-1 $\alpha$ expression was examined by RT-qPCR (Fig. 1C and E) and western blotting (Fig. 1D and F). An empty vector was used as a NC. The HIF-1 $\alpha$ protein expression levels were significantly reduced by $54.6 \pm 6.51$ and $58.3 \pm 6.59 \%$ in MZ-CRC-1 and TT cells transfected shRNA, respectively, compared with the untreated controls (Fig. 1D and $\mathrm{F} ; \mathrm{P}<0.01)$. No apparent changes in the $\mathrm{NC}$ were observed. 

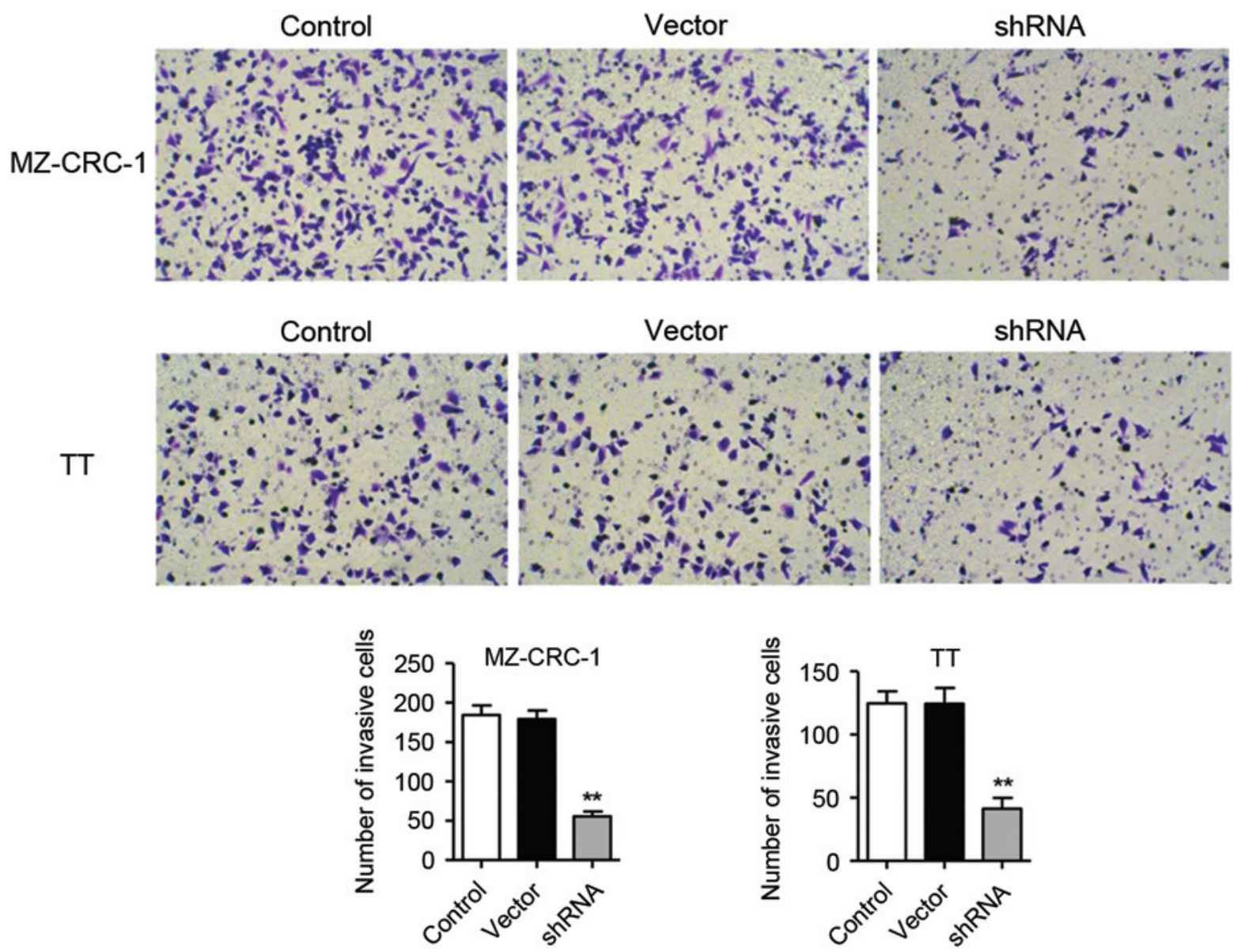

Figure 4. Effects of hypoxia-inducible factor-1 $\alpha$ on cell invasion in vitro. Martrigel transwell analysis was performed to determine the invasion of MZ-CRC-1 and TT cell (magnification, $\mathrm{x} 200$ ). ${ }^{* *} \mathrm{P}<0.01$ vs. the vector group. shRNA, small hairpin RNA.

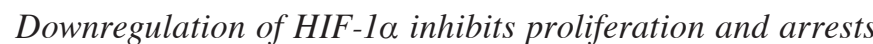
cell cycle in MZ-CRC-1 and TT cells. The thyroid carcinogenesis of HIF-1 $\alpha$ in MZ-CRC-1 and TT cells was explored. A significant reduction in cell proliferation of $43.1 \pm 0.073$ and $41.9 \pm 0.036 \% 72 \mathrm{~h}$ after shRNA transfection was identified in MZ-CRC-1 and TT cells, respectively (Fig. 2A; $\mathrm{P}<0.01$ ). In the absence of HIF-1 $\alpha$ shRNA, the cell populations were at G1, S, and G2 phases, and the addition of transfected shRNA resulted in a significant concomitant increase of the G1 phase in MZ-CRC-1 (47.9 $\pm 1.41 \%)$ and TT cells $(18.6 \pm 4.58 \%)$ (Fig. 2B; $\mathrm{P}<0.01$ ). In Fig. 2B, it is evident that the peak areas of sub-diploid were at the transfected shRNA. This observation suggests that the transfection of shRNA results in the arrest of the G1 phase.

Downregulation of HIF-1 $\alpha$ induces apoptosis and inhibits invasion in MZ-CRC-1 and TT cells. Cell apoptosis of cells transfected with shRNA was examined by flow cytometry. The results demonstrated that the apoptotic rate was significantly increased following HIF-1 $\alpha$ shRNA transfection in MZ-CRC-1 (>6.18-fold) and TT cells (>5.20-fold) compared with that in the $\mathrm{NC}$ group (Fig. 3; $\mathrm{P}<0.01$ ). The invasion abilities of MZ-CRC-1 and TT cells with stable knockdown of HIF-1 $\alpha$ were examined using a transwell assay. The invasive cells from the HIF- $1 \alpha$ knockdown MZ-CRC-1 and TT cells were $41.3 \pm 8.62$ and $55.3 \pm 6.51$, respectively, which were significantly less compared with the NC group (155 \pm 9.61 and $184 \pm 12.0$, respectively; Fig. $4 ; \mathrm{P}<0.01)$. These data suggest that HIF-1 $\alpha$ may function as a tumor promoter in thyroid cancer through the inhibition of cell apoptosis and induction of cell invasion.

$H I F-1 \alpha$ regulates angiogenic gene expression in $M Z-C R C-1$ and TT cells. To elucidate the underlying mechanisms by which HIF-1 $\alpha$ experts its function, the influence of HIF-1 $\alpha$ knockdown on WWP2, WWP9, VEGF and VEGFR2 levels was investigated, and shRNA was transfected into MZ-CRC-1 and TT cells. The indicated gene mRNA and protein expressions were significantly lower in MZ-CRC-1 cells compared with the NC group without HIF-1 $\alpha$ shRNA transfection (Fig. 5A and $\mathrm{B} ; \mathrm{P}<0.01$ ). The same was identified in HIF-1 $\alpha$ transfected WWP2, WWP9, VEGF and VEGFR2 levels (Fig. 5C and $\mathrm{D} ; \mathrm{P}<0.01$ ). The results clearly demonstrate that there is HIF- $1 \alpha$-dependent regulation of WWP2, WWP9, VEGF and VEGFR2 in thyroid cancer cell lines.

\section{Discussion}

Although thyroid cancer is the most common endocrine tumor, the mechanisms involved remain poorly understood. HIF-1 $\alpha$ is a member of the HIF-1 gene family, and is degraded in normoxic conditions but highly expressed in hypoxic 
A

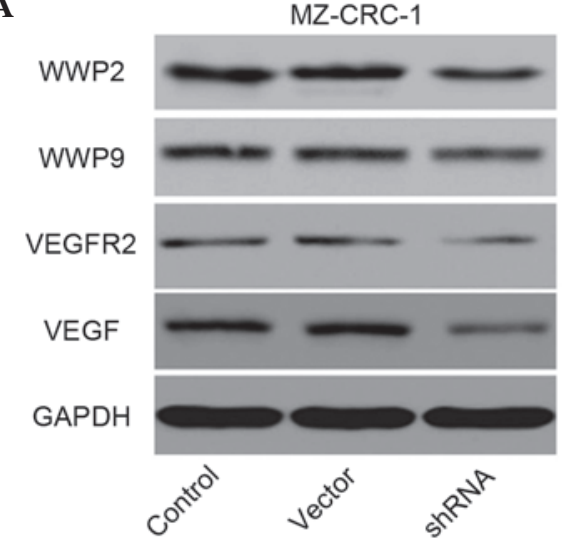

C

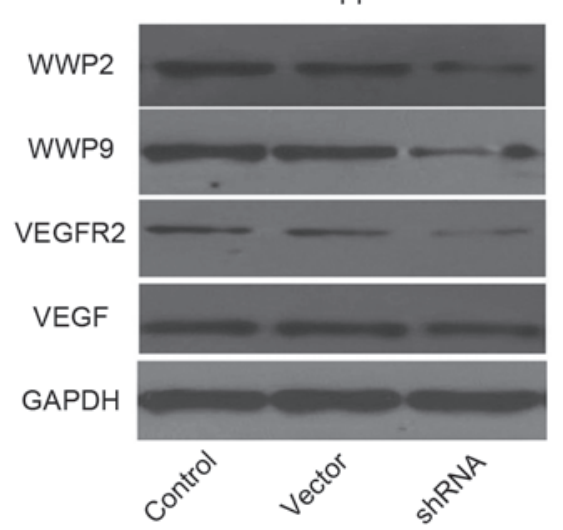

B

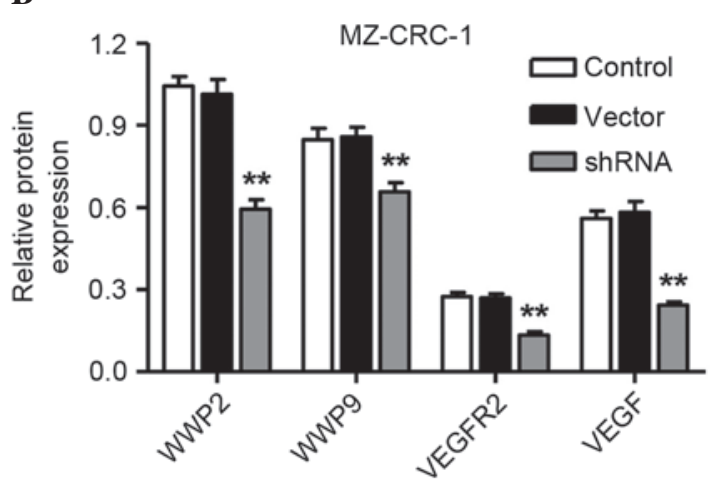

D

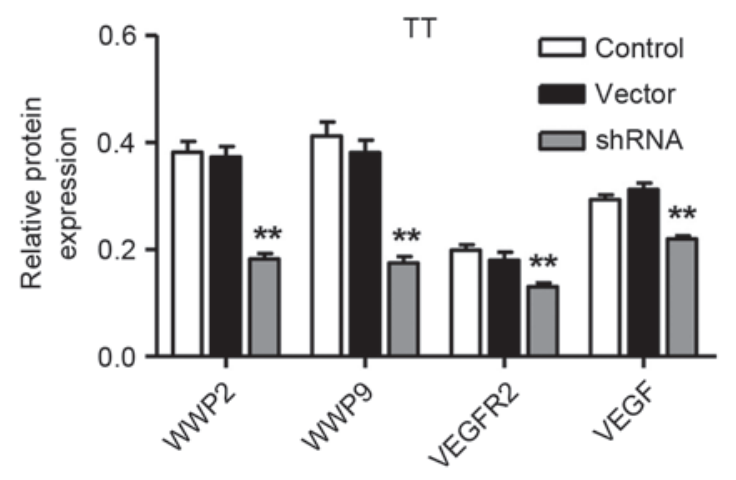

Figure 5. Effects of hypoxia-inducible factor-1 $\alpha$ (HIF-1 $\alpha$ ) on WWP2, WWP9, VEGF and VEGFR2 expression in MZ-CRC-1 and TT cells. MZ-CRC-1 cell (A) mRNA and (B) protein expression markers with stable knockdown of HIF-1 $\alpha$. TT cell (C) mRNA and (D) protein expression markers with stable knockdown of HIF-1 $\alpha$. ${ }^{* *} \mathrm{P}<0.01$ vs. the vector group. WWP, WW domain containing E3 ubiquitin protein ligase; VEGF, vascular endothelial growth factor; VEGFR2, VEGF receptor 2 .

conditions (18). It serves an important role in the development of tumor growth, angiogenesis, invasion and metastasis (19). In the present study, a potential role for HIF-1 $\alpha$ in promoting tumorigenesis in thyroid cancer is explored. HIF-1 $\alpha$ mRNA and protein were expressed in different thyroid cancer cell lines, but were found to expressed the highest in MZ-CRC-1 and TT cells. Upon in vitro culture, MZ-CRC-1 and TT cells stably expressing HIF-1 $\alpha$ shRNA expressed a decreased expression of HIF-1 $\alpha$, as measured by RT-qPCR and western blot analysis. In agreement, previous studies demonstrated that small interfering RNA-mediated knockdown of HIF-1 $\alpha$ expression in U251 and 786-O cells resulted in a remarkably stronger downregulation of HIF-1a expression $(20,21)$.

The results of the current study indicated the roles of HIF- $1 \alpha$ in human thyroid cancer carcinogenesis. Suppressing HIF-1 $\alpha$ expression notably inhibited the proliferation and arrested the cell cycle of MZ-CRC-1 and TT cells. The effects of HIF-1 $\alpha$ knockdown on the induction of apoptosis were then determined in MZ-CRC-1 and TT cells. Flow cytometry data indicated that downregulation of HIF-1 $\alpha$ resulted in a significant induction of apoptosis. Previously, a significant correlation between HIF-1 $\alpha$ and apoptosis was identified in NSCLC and LNCaP cells $(22,23)$. However, HIF-1 $\alpha$ is correlated with apoptosis, but has no association with proliferation in 60 cases of lung cancer (24). Victor et al (25) reported that HIF-1 $\alpha$ increased adhesion, migration and invasion of Mum2B cells. Similarly, the results of the present study demonstrated that downregulation of HIF-1 $\alpha$ resulted in significant inhibition of cell invasion in MZ-CRC-1 and TT cells. Because of its pro-apoptosis and pro-invasion role in human thyroid cancer, HIF-1 $\alpha$ may be a potential therapy target that should be further investigated.

The data in the current study raise the question of whether HIF-1 $\alpha$ is associated with tumorigenesis in thyroid cancer. Angiogenesis is a critical biological characteristic and an important mediator of cell growth and invasiveness in thyroid cancer. Therefore, the inhibition of angiogenesis is an effective method for the treatment of thyroid cancer, while the factors mediated by HIF-1 $\alpha$, which are involved in angiogenesis of thyroid cancer, have not been previously reported. In the present study, the effects of HIF-1 $\alpha$ on the expression of angiogenic genes were investigated. Matrix metalloproteinases (MMPs) are a family of enzymes that are important for tumor invasiveness contributing towards the remodeling of the extracellular matrix during growth and morphogenetic processes, which precede angiogenesis $(26,27)$. In the current study, two members of the MMP family, WWP2 and WWP9, were downregulated resulting from HIF-1 $\alpha$ knockdown in MZ-CRC-1 and TT cells. VEGF is an additional key mediator of angiogenesis, with two VEGF receptors, VEGFR1 and VEGFR2, expressed on vascular endothelial cells (28). In the current study, VEGF and VEGFR2 
were downregulated resulting from HIF-1 $\alpha$ knockdown in MZ-CRC-1 and TT cells. Previous studies demonstrated that the stimulation of VEGF and VEGFR2 production in thyroid cancer cells and breast cancer cells is dependent on HIF-1 $\alpha$, and appears to correlate with tumor formation $(29,30)$.

In conclusion, the present study demonstrated that HIF-1 $\alpha$ is upregulated in thyroid cancer cell lines, and that its knockdown represses cell invasion and induces apoptosis by downregulating the expression levels of WWP2, WWP9, VEGF and VEGFR2. These results indicate that HIF-1 $\alpha$ deregulation may serve important roles in tumor growth and invasion, and that HIF-1 $\alpha$ serve as a potential therapeutic target for the treatment of thyroid cancer.

\section{Acknowledgements}

The present study was supported by the Science and Technology Commission of Wuxi Municipality Fund (grant no. YGZXL1302).

\section{References}

1. Kondo T, Ezzat S and Asa SL: Pathogenetic mechanisms in thyroid follicular-cell neoplasia. Nat Rev Cancer 6: 292-306, 2006.

2. Sosa JA and Udelsman R: Papillary thyroid cancer. Surg Oncol Clin N Am 15: 585-601, 2006.

3. Hundahl SA, Fleming ID, Fremgen AM and Menck HR: A National Cancer Data Base report on 53,856 cases of thyroid carcinoma treated in the US, 1985-1995 [see comments]. Cancer 83: 2638-2648, 1998.

4. Marsh DJ, Learoyd DL and Robinson BG: Medullary thyroid carcinoma: Recent advances and management update. Thyroid 5 : 407-424, 1995.

5. Vaupel P: The role of hypoxia-induced factors in tumor progression. Oncologist 99 (Suppl 5): S10-S17, 2004.

6. Vleugel M, Greijer A, Shvarts A, van der Groep P, van Berkel M, Aarbodem Y, van Tinteren H, Harris AL, van Diest PJ and van der Wall E: Differential prognostic impact of hypoxia induced and diffuse HIF-1alpha expression in invasive breast cancer. J Clin Pathol 58: 172-177, 2005.

7. Kimbro KS and Simons JW: Hypoxia-inducible factor-1 in human breast and prostate cancer. Endocr Relat Cancer 13: 739-749, 2006.

8. Semenza GL: Targeting HIF-1 for cancer therapy. Nat Rev Cancer 3: 721-732, 2003.

9. Pouysségur J, Dayan F and Mazure NM: Hypoxia signalling in cancer and approaches to enforce tumour regression. Nature 441: 437-443, 2006

10. Amelio I and Melino G: The 'Sharp' blade against HIF-mediated metastasis. Cell Cycle 11: 4530-4535, 2012.

11. Scarpino S, Cancellario d'Alena F, Di Napoli A, Pasquini A, Marzullo A and Ruco LP: Increased expression of Met protein is associated with up-regulation of hypoxia inducible factor-1 (HIF-1) in tumour cells in papillary carcinoma of the thyroid. J Pathol 202: 352-358, 2004.

12. Burrows N, Resch J, Cowen RL, von Wasielewski R, Hoang-Vu C, West CM, Williams KJ and Brabant G: Expression of hypoxia-inducible factor 1alpha in thyroid carcinomas. Endocr Relat Cancer 17: 61-72, 2010.
13. Yang QC, Zeng BF, Shi ZM, Dong Y, Jiang ZM, Huang J, Lv YM, Yang CX and Liu YW: Inhibition of hypoxia-induced angiogenesis by trichostatin A via suppression of HIF-la activity in human osteosarcoma. J Exp Clin Cancer Res 25: 593-599, 2006.

14. Kyzas PA, Stefanou D, Batistatou A and Agnantis NJ: Hypoxia-induced tumor angiogenic pathway in head and neck cancer: An in vivo study. Cancer Lett 225: 297-304, 2005.

15. Ioannou M, Papamichali R, Kouvaras E, Mylonis I, Vageli D, Kerenidou T, Barbanis S, Daponte A, Simos G, Gourgoulianis K and Koukoulis GK: Hypoxia inducible factor-1 alpha and vascular endothelial growth factor in biopsies of small cell lung carcinoma. Lung 187: 321-329, 2009.

16. Litz $\mathrm{J}$ and Krystal GW: Imatinib inhibits c-Kit-induced hypoxia-inducible factor-1alpha activity and vascular endothelial growth factor expression in small cell lung cancer cells. Mol Cancer Ther 5: 1415-1422, 2006.

17. Payton JE, Grieselhuber NR, Chang LW, Murakami M, Geiss GK, Link DC, Nagarajan R, Watson MA and Ley TJ: High throughput digital quantification of mRNA abundance in primary human acute myeloid leukemia samples. J Clin Invest 119: 1714-1726, 2009.

18. Harris AL: Hypoxia-a key regulatory factor in tumour growth. Nat Rev Cancer 2: 38-47, 2002.

19. Zagzag D, Zhong H, Scalzitti JM, Laughner E, Simons JW and Semenza GL: Expression of hypoxia-inducible factor 1alpha in brain tumors: Association with angiogenesis, invasion and progression. Cancer 88: 2606-2618, 2000.

20. Jensen RL, Ragel BT, Whang K and Gillespie D: Inhibition of hypoxia inducible factor-1alpha (HIF-1alpha) decreases vascular endothelial growth factor (VEGF) secretion and tumor growth in malignant gliomas. J Neurooncol 78: 233-247, 2006.

21. Song T, Zhang X, Wang C, Wu Y, Cai W, Gao J and Hong B: MiR-138 suppresses expression of hypoxia-inducible factor $1 \alpha$ (HIF-1 $\alpha$ ) in clear cell renal cell carcinoma 786-O cells. Asian Pac J Cancer Prev 12: 1307-1311, 2011.

22. Chen B, Yuping S and Ni J: Rapamycin decreases survivin expression to induce NSCLC cell apoptosis under hypoxia through inhibiting HIF-1 $\alpha$ induction. Mol Biol Rep 39: 185-191, 2012.

23. Ghafar MA, Anastasiadis AG, Chen MW, Burchardt M, Olsson LE, Xie H, Benson MC and Buttyan R: Acute hypoxia increases the aggressive characteristics and survival properties of prostate cancer cells. Prostate 54: 58-67, 2003.

24. Fan LF, Diao LM, Chen DJ, Liu MQ, Zhu LQ, Li HG, Tang ZJ, Xia D, Liu X and Chen HL: Expression of HIF-1 alpha and its relationship to apoptosis and proliferation in lung cancer. $\mathrm{Ai}$ Zheng 21: 254-258, 2002 (In Chinese).

25. Victor N, Ivy A, Jiang BH and Agani FH: Involvement of HIF-1 in invasion of Mum2B uveal melanoma cells. Clin Exp Metastasis 23: 87-96, 2006.

26. Chang $\mathrm{C}$ and Werb Z: The many faces of metalloproteases: Cell growth, invasion, angiogenesis and metastasis. Trends Cell Biol 11: S37-S43, 2001.

27. John A and Tuszynski G: The role of matrix metalloproteinases in tumor angiogenesis and tumor metastasis. Pathol Oncol Res 7: 14-23, 2001.

28. Carmeliet P: VEGF as a key mediator of angiogenesis in cancer. Oncology 69 (Suppl 3): S4-S10, 2005.

29. Poulaki V, Mitsiades CS, McMullan C, Sykoutri D, Fanourakis G, Kotoula V, Tseleni-Balafouta S, Koutras DA and Mitsiades N: Regulation of vascular endothelial growth factor expression by insulin-like growth factor I in thyroid carcinomas. J Clin Endocrinol Metab 88: 5392-5398, 2003.

30. Gonzalez-Perez RR, Xu Y, Guo S, Watters A, Zhou W and Leibovich SJ: Leptin upregulates VEGF in breast cancer via canonic and non-canonical signalling pathways and NFkappaB/HIF-1alpha activation. Cell Signal 22: 1350-1362, 2010. 